\title{
PELATIHAN PEMBELAJARAN DARINGBAGI GURU-GURU SEKOLAH DASAR GUNA MENINGKATKAN LITERASI DIGITAL DI MASA PANDEMI COVID-19
}

\author{
Jefrey Oxiannus Sabarua ${ }^{1)}$, Jonherz Stenlly Patalatu' ${ }^{2)}$, Stefen Deni Besare ${ }^{3)}$ \\ 1,2,3) Pendidikan Guru Sekolah Dasar, Universitas Halmahera \\ 1)joxianus@gmail.com, ${ }^{2)}$ patalatu@gmail.com, ${ }^{3)}$ besarestefen@gmail.com
}

\section{Histori artikel \\ Received: \\ 8 November 2020 \\ Accepted: \\ 23 November 2020 \\ Published: \\ 30 November 2020}

\begin{abstract}
Abstrak
Persoalan yang mendasari pengabdian kepada masyarakat ini ialah keterbatasan keterampilan guru SD GMIH 4 Tobelo dalam menyelenggarakan proses pembelajaran secara daring menggunakan fitur-fitur online. Tujuan pengabdian ini adalah memberikan pemahaman serta keterampilan dalam memanfaatkan fitur-fitur online sebagai media pembelajaran daring. Metode pelatihan dilakukan dengan ceramah, diskusi, dan latihan. Hasil kegiatan pengabdian ini yaitu; guru-guru memahami fitur-fitur yang digunakan dalam melaksanakan pembelajaran daring, memiliki keterampilan dalam mengugunakan fitur-fitur online seperti zoom meeting, dan google classroom. Manfaat lain dari pelatihan ini yang diperoleh selain dapat melakukan pembelajaran secara daring, peserta juga dibekali dengan keterampilan membuat video pembelajaran menggunakan fitur zoom meeting dengan cara mereka pemeparan materi yang disertai dengan tampilan materi pembelajarannya. Hal ini merupakan salah satu strategi untuk melaksanakan pembelajaran berbasis luring, sehingga para peserta didik tidak bergantung pada jaringan internet.
\end{abstract}

Kata-kata Kunci : pembelajaran daring, zoom meeting, google classroom, pembelajaran luring 
Abstrak. The problem that underlies this community service is the limited skills of SD GMIH 4 Tobelo teachers in organizing the learning process online using online features. The purpose of this service is to provide understanding and skills in utilizing online features as an online learning medium. The training method is carried out by lectures, discussions and exercises. The results of this service activity, namely; teachers understand the features used in implementing online learning, have skills in using online features such as zoom meeting, and google classroom. Other benefits from this training are obtained in addition to being able to conduct online learning, participants are also equipped with the skills to make learning videos using the zoom meeting feature by presenting the material accompanied by a display of the learning material. This is one of the strategies for implementing offline-based learning, so that students do not depend on the internet network.

Kata-kata Kunci : online learning, zoom meeting, google classroom, offline learning

\section{PENDAHULUAN}

Indonesia adalah salah satu negara yang terdampak pandemic covid 19. Oleh karena itu, Kementerian Pendidikan dan Kebudayaan (Kemendikbud) melalui Surat Edaran No. 4 Tahun 2020, menghimbau agar satuan Pendidikan menyelenggarakan pembelajaran dari rumah (Kemendikbud, 2020). Selain itu, melalui Surat Edaran No. 15 tahun 2020, Kemendikbud menegaskan bahwa pembelajaran dari rumah dilakukan dengan cara daring dan luring (Kementerian Pendidikan Dan Kebudayaan, 2020). Dengan demikian, maka seluruh Satuan Pendidikan dituntut untuk dapat melaksanakan pembelajaran sesuai dengan instruksi Menteri.

Berkenaan dengan itu, setiap pendidik harus memiliki keterampilan dalam memanfaatkan teknologi digital dalam pembelajaran (Fitriah \& Mirianda, 2019). Akan tetapi, fakta di lapangan menunjukkan bahwa masih banyak para pendidik khususnya yang berada di wilayah Indonesia bagian timur yang belum sepenuhnya memiliki keterampilan tersebut. Pembelajaran berbasis digitalisasi sebagaimana dimaksud, masih merupakan hal baru khususnya pemanfaatan fiturfitur online yang digunakan untuk menyelenggarakan pembelajaran secara daring, maupun mendesain materi pelajaran menggunakan aplikasi (Hidayat \& Khotimah, 2019).

Sebagaimana kita ketahui bahwa pemanfaatan teknologi digital dalam pembelajaran merupakan salah satu bentuk upaya dalam meningkatkan kualitas pembelajaran (Setyaningsih et al., 2019). Melalui pemanfaatan media digital, pendidik dapat mendesain materi pembelajaran yang menarik dan inovatif (Desi, 2019). Materi yang didesain dapat pula disesuaikan dengan tingkat perkembangan dan minat peserta didik berdasarkan tingkatan kelas, baik kelas rendah maupun kelas tinggi.

Kemudahan lainnya dalam memanfaatkan teknologi digital yaitu memudahkan pendidik dalam memperkaya materi ajarnya melalui informasi-informasi aktual yang dapat diakses melalui jaringan internet (Nahdi \& Jatisunda, 2020). Selain itu, proses pembelajarannya pun 
dapat didesain virtual, sehingga antara pendidik dan peserta didik tidak perlu bertatap muka secara langsung di kelas. Materi ajar dapat pula didesain dalam bentuk video interaktif, dengan menampilkan gambar-gambar yang menarik perhatian siswa, sehingga pembelajaran tidak membosankan (Masitoh, 2018).

Sehubungan dengan itu, hasil penelitian sebelumnya menunjukkan bahwa sebagian pendidik Sekolah Dasar di Kabupaten Halmahera Utara belum memiliki keterampilan dalam memanfaatkan fitur-fitur online yang digunakan untuk pembelajaran secara daring. Akibatnya, proses pembelajaran yang dilaksanakan terkesan kurang menarik dan membosankan serta menguras banyak energi. Adapun proses pembelajaran yang sering digunakan adalah dengan cara memberikan modul, melakukan pembelajaran di kelas dengan cara bergantian, menghampiri siswa di rumahnya masing-masing, dan lain sebagainya (Petrus et al., 2020).

Sebagaimana kita ketahui bahwa pembelajaran di masa pandemic menuntut para pendidik agar dapat memiliki keterampilan dalam pemanfaatan IT. Melalui pemanfaatan teknologi digital, pendidik memperoleh berbagai kemudahan dalam hal merancang bahan ajar, mencari referensi tambahan/bahan pengayaan dan memberikan wawasan global kepada peserta didik (Firman \& Rahman, 2020).

Kondisi tersebut dipicu oleh ketidaksiapan para pendidik dalam menghadapi pembelajaran berbasis digital yang ditinjau dari aspek sikap, emosi, pengetahuan dan keterampilan. Sebagian pendidik menganggap bahwa melaksanakan pembelajaran berbasis digital tidak mudah untuk diterapkan karena harus memiliki keterampilan khusus dalam teknologi digital. Di sisi lain secara emosi, para pendidik di SD GMIH 4 Tobelo tetap antusias dalam menyelenggarakan pembelajaran secara konvensional, walaupun dalam regulasi dituntut untuk melaksanakan pembelajaran secara daring dan atau luring.

Ditinjau dari aspek pengetahuan, para pendidik di SD GMIH 4 Tobelo memiliki kendala dalam pemahaman akan pembelajaran yang dilakukan secara daring. Hal ini terlihat dari tanggapan beberapa pendidik yang mengatakan bahwa mereka tidak paham fitur-fitur seperti zoom meeting, google classroom, dan fitur lainnya seperti aplikasi pembuat video untuk pembelajaran luring. Selain itu, usia yang sudah tidak muda lagi menyebabkan sebagian pendidik tidak memperbaharui pengetahuannya terkait pembelajaran berbasis digitalisasi.

Sehubungan dengan itu, seorang pendidik memiliki tanggung jawab dalam mencerdaskan generasi bangsa. Oleh sebab itu, perlu adanya pengembangan terhadap kompetensi yang dimiliki dengan cara memperbaharui pengathuan yang dimiliki melalui bacaan dan berbagai informasi terkait perkembangan pembelajaran yang sedang berlangsung khususnya pada 
jenjang sekolah dasar. Hal ini dimaksud agar para suatu saat para pendidik mampu untuk beradaptasi dengan perubahan-perubahan yang terjadi seperti pada situasi pandemic saat ini (Yanzi et al., 2019).

Sementara itu, ditinjau dari aspek keterampilan, sebagian besar pendidik di SD GMIH 4 Tobelo belum memiliki keterampilan dalam menggunakan aplikasi dan fitur-fitur dalam melaksanakan pembelajaran berbasis daring. Hal ini terlihat pada saat melaksanakan pembelajaran, para pendidik tetap menyelenggarakan pembelajaran secara konvensional, walaupun harus menghampiri para peserta didik di rumahnya masing-masing.

Pentingnya memiliki keterampilan memanfaatkan teknologi digital dalam pembelajaran dapat mempermudah pendidik dalam mendesain pembelajaran yang menarik dan interaktif. Pendidik dapat merancang materi pembelajarannya secara elektronik sehingga peserta didik dapat mengaksesnya secara luring maupun daring. Kelebihan lainnya dalam memanfaatkan teknologi digital ialah pendidik dapat mengakses berbagai informasi penting terkait materi pembelajaran yang dapat dijadikan sebagai materi pendamping (Astini, 2019).

Selain hal tersebut, masalah jaringan internet dan listrik juga menjadi salah satu factor penghambat dalam melaksanakan pembelajaran secara daring. Para pendidik merasa bahwa pembelajaran daring dalam situasi seperti yang demikian adalah sebuah usaha yang sia-sia. Dengan demikian, maka pada situasi seperti inilah para pendidik mengalami hambatan dalam mengembangkan desain pembelajaran yang menarik dan kreatif. Akan tetapi, dalam pembelajaran daring maupun luring, pemahaman dan keterampilan teknologi digital sangat bermanfaat.

Seperti yang kita ketahui bahwa pembelajaran di masa pandemic ini menuntut para pendidik agar dapat berinovasi dalam mendesain pembelajaran dengan memanfaatkan teknologi digital sehingga dapat menfasilitasi peserta didik belajar dari rumah. Keterampilan dalam memanfaatkan teknologi digital juga sangat bermanfaat dalam pembelajaran daring maupun luring. Dengan memanfaatkan video pembelajaran, pendidik dapat menfasilitasi peserta didik yang mengalami kendala dalah hal jaringan internet, sehingga pembelelajaran dapat diakses secara offline dengan memanfaatkan media elektonik seperti HP, laptop, dan atau komputer desktop.

Berdasarkan kondisi tersebut, maka pengabdian ini bertujuan untuk memberikan pemahaman dan pelatihan kepada pendidik di SD GMIH 4 Tobelo dalam menggunakan zoom meeting dan google classroom pembelajaran online atau daring pada masa pandemic covid-19. 


\section{METODE PELAKSANAAN}

Pelaksanaan pelatihan pembelajaran daring dilaksanakan selama 1 bulan yaitu pada bulan April 2020, dengan pesertanya adalah para pendidik di SD GMIH 4 Tobelo. Pelatihan ini bertujuan untuk memberikan pemahaman dan keterampilan pendidik dalam memanfaatkan zoom meeting dan google classroom dalam melaksanakan pembelajaran daring dan atau luring. Adapun indicator keberhasilan dalam kegiatan pelatihan ini adalah jika terdapat $80 \%$ peserta yang mampu memahami dan melaksanakan pembelajaran secara daring dan atau luring. Berikut metode pelaksanaan yang digunakan dalam kegiatan pengabdian kepada masyarakat ini meliputi;

1. Metode Ceramah

Aktifitas yang dilakukan melalui metode ceramah ialah pemberian materi terkait pembelajaran berbasis daring, dengan memanfaatkan fitu-fitur online serta mendesain materi ajar dalam bentuk video pembelajaran yang menarik. Adapun materi yang diberikan meliputi zoom meeting dan google classroom. Kegiatan ini dilaksanakan pada hari pertama dan kedua.

2. Metode Tanya Jawab

Pada saat memberikan materi, peserta diberikan kesempatan untuk melakukan interaksi tanya jawab terkait dengan hal-hal yang belum dipahami. Hal ini dilakukan agar materi yang diberikan dapat terserap dengan baik oleh peserta kegiatan.

3. Metode Latihan/Praktek

Setelah materi dipahami dengan baik, kemudian peserta diberikan tugas untuk melakukan latihan-latihan pembelajaran menggunakan zoom meeting dan google classroom. Dengan melakukan Latihan, diharapkan perserta dapat lebih memahami dan mengaplikasikan fiturfitur tersebut dalam proses pembelajaran secara daring. Pelaksanaan sesi Latihan dan praktek dilakukan pada hari ketiga, hingga hari kelima. Adapun rincian kegiatannya terdiri dari; hari ketiga dan keempat dilakukan pelatihan, kemudian pada hari kelima dilakukan evaluasi pelaksanaan kegiatan pelatihan.

\section{HASIL DAN PEMBAHASAN}

\section{Hasil}

Kegiatan pengabdian pelatihan pembelajaran daring dilaksanakan selama 1 bulan, yaitu pada bulan April 2020. Pelaksanaan kegiatan ini didasari oleh kesepakatan bersama kepala sekolah dan para pendidik di SD GMIH 4 Tobelo, guna menghadapi tantangan model 
pembelajaran di masa pandemic covid-19. Kegiatan ini dilaksanakan selama satu minggu berjalan, kemudian dilakukan pendampingan selama satu bulan penuh guna memantapkan keterampilan para pendidik dalam memanfaatkan fitur-fitur digital dalam pembelajaran berbasis daring. Peserta kegiatan berjumlah 12 orang yang terdiri dari 6 orang adalah ASN, 2 orang kontrak daerah, dan 4 orang lainnya adalah pegawai honor. Kegiatan dilakukan setelah jam pelajaran, sehingga tidak mengganggu aktifitas mengajar yang sudah dijadwalkan oleh sekolah. Dengan demikian maka, pelaksanaan kegiatan ini dapat berjalan dengan baik dan lancar.

Kegiatan diawali dengan pemberian materi melalui seminar pembelajaran daring menggunakan fitur zoom meeting dan google classroom. Narasumber memberikan penjelasan terkait pengenalan dan pemanfaatan fitur-fitur yang dapat diaplikasikan dalam proses pembelajaran secara daring maupun luring. Antusiasme peserta dalam mengikuti sesi ini sangat baik, yang ditunjukkan melalui interaksi antara peserta dan narasumber selama sesi materi berlangsung. Peserta diberikan kesempatan untuk bertanya seputar materi yang disampaikan oleh narasumber terkait bagaimana mengakses dan memanfaatkan fitur-fitur dimaksud.

Berdasarkan hasil seminar tentang pengenalan dan pemahaman zoom meeting dan google classroom, ditemukan 95\% peserta seminar memahami fitur-fitur tersebut dengan baik. Namun 5\% lainnya tetap dilakukan pendampingan hingga memahami materi yang diberikan dengan baik.

Berkenaan dengan proses pelatihan, terdapat beberapa kendala dalam pelaksanaannya di antaranya jaringan internet yang tidak stabil, sehingga menghambat peserta dalam mengakses fitur-fitur tersebut. Kendala berikutnya adalah pemadaman listrik yang bertepatan dengan berlangsungnya kegiatan pelatihan. Namun dikarenakan antusiasme peserta yang sangat tinggi, kendala tersebut tidaklah menjadi halangan bagi mereka untuk terus belajar dan mengasah keterampilannya dalam memanfaatkan fitur-fitur online dalam proses pembelajaran daring.

Sehubungan dengan itu, peserta peserta juga dapat membuat video pembelajaran menggunakan fitur zoom meeting dengan cara merekam sendiri paparan materi pelajaran dan menampilkan materi tersebut dalam bentuk word, PPT, dan atau video. Hal ini dilakukan untuk memfasilitasi peserta didik secara luring, sehingga mereka dapat mengaksesnya tanpa harus bergantung pada jaringan internet. Pada sesi pelatihan pembelajaran daring, para pendidik sudah dapat menggunakannya walaupun masih terkendala beberapa hal teknis. Akan tetapi tim tetap pakan melakukan pendampingan hingga para pendidik dapat mandiri dalam melaksanakan proses pembelajaran berbasis daring. 
Hasil dari pelatihan menunjukkan bahwa $80 \%$ peserta yang mengikuti pelatihan dapat menggunakan fitur zoom meeting dan google classroom, baik dalam melaksanakan proses pembelajaran, maupun membuat video pembelajaran. Akan tetapi, 20\% lainnya masih terkendala dalam pemanfaat google classroom, sehingga membutuhkan pendampingan lebih lanjut.

\section{Pembahasan}

Bertolak dari kebutuhan akan pembelajaran di masa pandemic covid-19 yang menuntut para pendidik untuk mampu memanfaatkan media digital dalam melaksanakan proses pembelajaran, maka tim dosen PGSD Universitas Halmahera dan SD GMIH 4 Tobelo, berinisiatif untuk melakukan pelatihan pembelajaran daring kepada para pendidik di SD GMIH 4 Tobelo. Adapun kegiatan pelatihan dilakukan selama satu minggu, namun tim tetap memberikan pendampingan kepada peserta selama satu bulan hingga peserta dapat mandiri dalam melaksanakan proses pembelajaran secara daring.

Kegiatan pengabdian ini merupakan salah satu bentuk respon terhadap himbauan pemerintah terkait proses pembelajaran dilakukan dari rumah secara daring dan atau luring yang tertuang dalam Surat Edaran Kementerian Pendidikan dan Kebudayaan No. 4 tahun 2020, tentang pelaksanaan kebijakan Pendidikan dalam masa darurat penyebaran corona virus disease (Covid-19), dan ditegaskan kembali pada Surat Edaran Kemendikbud No. 15 tahun 2020 tentang pedoman penyelenggaraan belajar dari rumah dalam masa darurat penyebaran corona virus disease (Covid-19).

Melalui kegiatan pelatihan yang dilakukan oleh tim dosen PGSD Universitas Halmahera, para pendidik di lingkup SD GMIH 4 Tobelo telah mampu mengaplikasikan fitur zoom meeting dan google classroom dalam interaksi pembelajaran baik secara daring, maupun luring.

Sebagaimana kita ketahui bahwa pembelajaran di masa pandemic covid-19 menuntut para pendidik untuk dapat meningkatkan keterampilan mengajarnya melalui pemahaman serta wawasan yang luas terkait pemanfaatan media teknologi dalam proses pembelajaran (Lase, 2019). Meskipun demikian, masih pendidik di beberapa daerah yang masih belum memanfaatkan media teknologi dalam pembelajarannya. Hal ini dikarenakan tidak adanya keterampilan pendidik dalam menggunakan teknologi, sehingga pembelajaran yang berlangsung masih bersifat tradisional (Jamaluddin et al., 2020). 


\section{DAFTAR PUSTAKA}

Astini, N. K. S. (2019). Pentingnya literasi teknologi informasi dan komunikasi bagi guru sekolah dasar untuk menyiapkan generasi milenial. Prosiding Seminar Nasional Dharma Acarya Ke-1 STAHN Mpu Kuturan, 113-121, 113-120.

Desi, Y. P. (2019). Gerakan literasi digital berbasis sekolah: Implementasi dan strategi. Jurnal IImu Komunikasi, 17(1), 51-59.

Firman, F., \& Rahman, S. R. (2020). Pembelajaran online di tengah pandemi covid-19. Indonesian Journal of Educational Science (IJES), 2(2), 81-89.

Fitriah, D., \& Mirianda, M. U. (2019). Kesiapan guru dalam menghadapi tantangan pendidikan berbasis teknologi. Prosiding seminar nasional pendidikan program pascasarjana universitas PGRI, 148-153.

Hidayat, N., \& Khotimah, H. (2019). Pemanfaatan teknologi digital dalam kegiatan pembelajaran. Jurnal Pendidikan \& Pengajaran Guru Sekolah Dasar, 2(1), 10-15.

Jamaluddin, D., Ratnasih, T., Gunawan, H., \& Paujiah, E. (2020). Pembelajaran daring masa pandemik covid-19 pada calon guru: Hambatan, solusi dan proyeksi. Karya Tulis IImiah UIN Sunan Gunung Djjati Bandung, 1-10.

Kemendikbud. (2020). Pelaksanaan kebijakan pendidikan dalam masa darurat penyebaran corona virus disease (covid-19). SURAT EDARAN NOMOR 4 TAHUN 2020.

Kementerian Pendidikan Dan Kebudayaan. (2020). Pedoman penyelenggaraan belajar dari rumah dalam masa darurat penyebaran corona virus disease (covid-19). Surat Edaran Nomor 15 Tahun 2020, 1-20.

Lase, D. (2019). Pendidikan di era revolusi industri 4.0 education. Jctes, 1(1), 28-43.

Masitoh, S. (2018). Blended learning berwawasan literasi digital suatu upaya meningkatkan kualitas pembelajaran dan membangun generasi emas 2045. Proceedings of the ICECRS, 1(3), 13-34.

Nahdi, D. S., \& Jatisunda, M. G. (2020). Analisis literasi digital calon guru SD dalam pembelajaran berbasis virtual classroom di masa pandemi covid-19. Jurnal Cakrawala Pendas, 6(2), 116-123.

Petrus, J., Yeni, A., Wote, V., Patalatu, J. S., \& Sabarua, J. O. (2020). Melek digital : Tantangan guru di kabupaten halmahera utara saat pandemi covid-19. Dibawakan Pada International Conference on Technology and Educational Science (ICTES) 2020.

Setyaningsih, R., Abdullah, A., Prihantoro, E., \& Hustinawaty, H. (2019). Model penguatan literasi digital melalui pemanfaatan e-learning. Jurnal ASPIKOM, 3(6), 1200.

Yanzi, H., Nafilah, Susana, \& Patmawati, S. (2019). Urgensi guru sd era abad 21 dalam merespon revolusi industri 4.0. Prosiding Seminar Nasional Pendidikan, 324-334. 
